\title{
Identifikasi Kesulitan Belajar Mahasiswa pada Mata Kuliah Statistika Selama Masa Pandemi Covid-I9
}

\author{
Deci Ririen*, Dewi Hartika \\ Sekolah Tinggi Ilmu Ekonomi Indragiri \\ *Correspondence email: deciririen@stieindragiri.ac.id; dewihartika@stieindragiri.ac.id
}

\begin{abstract}
Abstrak. Lamanya masa pembelajaran secara daring di Perguruan Tinggi yang sudah berlangsung lebih kurang 10 bulan membuat mahasiswa resah, karena mayoritas mahasiswa menganggap mata kuliah statistika adalah mata kuliah yang sulit untuk dipahami, apalagi disertai dengan kondisi pandemi Covid-19. Tujuan dari penelitian ini untuk mengetahui faktor-faktor penyebab kesulitan belajar mahasiswa pada mata kuliah Statistika selama masa pandemi Covid-19 dan untuk mengetahui faktor dominan penyebab kesulitan belajar mahasiswa pada mata kuliah Statistika selama masa pandemi Covid-19. Subjek penelitian adalah mahasiswa STIE-Indragiri yang mengambil mata kuliah Statistika. Instrumen penelitian melalui angket dan wawancara kepada subjek penelitian. Hasil yang didapat yakni faktor-faktor yang menjadi kesulitan belajar mahasiswa pada mata kuliah statistika selama masa pandemi Covid-19 adalah faktor diri sendiri, faktor dosen, faktor lingkungan/ orang tua serta faktor sarana dan prasarana. Faktor yang paling dominan berpengaruh terhadap kesulitan belajar mahasiswa pada mata kuliah statistika selama masa pandemi Covid-19 adalah faktor sarana prasarana dengan nilai TCR 64,38\%.
\end{abstract}

Kata Kunci: Kesulitan Belajar; Pandemi Covid-19; Statistika

Abstract. The length of the online learning period in tertiary institutions that has lasted for approximately 10 months has made students uneasy, because the majority of students consider statistics courses to be difficult to understand, especially with the Covid-19 pandemic conditions. The purpose of this study was to determine the factors that caused student learning difficulties in the Statistics course during the Covid-19 pandemic and to determine the dominant factors causing student learning difficulties in the Statistics course during the Covid-19 pandemic. The research subjects were STIE-Indragiri students taking Statistics courses. Instruments of the research method through questionnaires and interviews with research subjects. The results obtained were the factors that made learning difficulties for students in the statistics course during the Covid-19 pandemic, namely the factors themselves, lecturers' factors, environmental factors / parents as well as facilities and infrastructure factors. The most dominant factor affecting student learning difficulties in statistics courses during the Covid-19 pandemic was the infrastructure factor with a TCR value of $64.38 \%$.

Keywords: Learning Difficulties; Covid-19 pandemic; Statistics

\section{PENDAHULUAN}

Mata kuliah statistika merupakan mata kuliah yang sangat penting dipahami mahasiswa karena berkaitan erat dengan penulisan skripsi. Kesiapan mahasiswa serta ketelitian dan daya pikir analitis dibutuhkan untuk memulai setiap pertemuan mata kuliah statistika. Oleh karena itu berdasarkan penelitian Ririen (2019) mayoritas mahasiswa beranggapan mata kuliah statistika adalah mata kuliah yang sulit untuk dipahami. Kesulitan belajar yang dialami mahasiswa semakin bertambah selama masa pandemi covid-19 (Corona Virus Disease-2019).

Covid-19 mulai dikonfirmasi pertama kali di Indonesia pada tanggal 2 Maret 2020 yang diumumkan oleh Presiden Republik Indonesia Joko Widodo. Sampai saat ini tidak kurang dari 200 Negara yang terdampak pandemi dengan kasus terkonfirmasi positif Covid-19 lebih dari 17.000.000 jiwa. Oleh karena itu, pemerintah mulai mengganti proses pembelajaran tatap muka di kelas dengan pembelajaran dari rumah pada semua jenjang, mulai dari pendidikan dasar sampai perguruan tinggi. Berdasarkan Keputusan Bersama 4 (empat) Kementerian yaitu Kementerian Pendidikan dan
Kebudayaan, Kementerian Kesehatan, Kementerian Agama serta Kementerian Dalam Negeri tentang pencegahan penularan Covid-19 pada jenjang Perguruan Tinggi, maka pembelajaran wajib dilaksanakan secara daring (dalam jaringan) untuk semester ganjil Tahun Ajaran 2020/2021.

Diperpanjangnya masa pembelajaran secara daring di Perguruan Tinggi membuat mahasiswa resah, dikarenakan mereka sudah menjalani selama lebih kurang 4 (empat) bulan pembelajaran daring untuk semester genap Tahun Ajaran 2019/2020. Masalah yang dikemukakan mahasiswa antara lain banyaknya tugas yang diberikan masing-masing dosen yang harus dikerjakan dalam waktu sempit, interaksi antara mahasiswa dengan dosen yang terbatas, masalah kuota dan jaringan serta kendala teknis lainnya. Adapun faktor penyebab kesulitan belajar mahasiswa diantaranya adalah faktor dari mahasiswa itu sendiri, faktor dari dosen, faktor lingkungan/ orangtua serta sarana prasarana.

Jika dilihat dari perbandingan hasil ujian akhir semester (UAS) mahasiswa selama masa pra pandemi covid-19 Tahun Ajaran 2018/2019 dan masa pandemi 
Covid-19 Tahun Ajaran 2019/2020 disajikan pada Gambar di bawah ini.

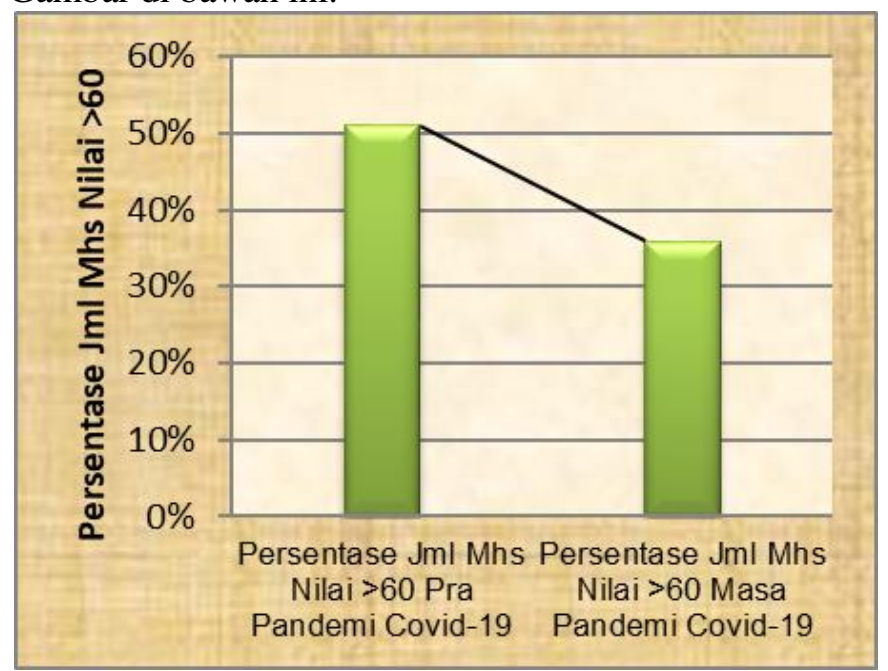

Gambar 1. Perbandingan Persentase Jumlah Mahasiswa dengan Nilai UAS Statistika >60 Pra dan Masa Pandemi Covid-19

Terlihat dari Gambar 1 menunjukkan persentase jumlah mahasiswa dengan nilai UAS Statistika yang > 60 pada masa sebelum (pra) pandemi Covid-19 sebesar $51 \%$, sedangkan persentase jumlah mahasiswa dengan nilai UAS Statistika yang > 60 pada masa pandemi Covid-19 sebesar 35,88\%. Hal ini bukanlah harapan dosen maupun mahasiswa, mengingat persentase nilai UAS mahasiswa yang $>60$ sebelum masa pandemi lebih besar daripada masa pandemi. Rendahnya nilai mahasiswa pada mata kuliah Statistika untuk T.A 2019/2020 salah satunya dapat disebabkan mahasiswa belum dapat beradaptasi dengan proses pembelajaran daring (dalam jaringan) pada kondisi pandemi Covid-19. Hasil penelitian yang didapatkan oleh Zamista (2020) juga menemukan bahwa peserta didik memiliki persepsi yang negatif terhadap pembelajaran daring dan penelitian Harahap (2020) menemukan bahwa peserta didik masih memerlukan self regulated learning agar dapat beradaptasi dengan baik selama masa pandemi. Oktawirawan (2020) juga melakukan penelitian mengenai faktor pemicu kecemasan peserta didik selama pembelajaran daring yaitu kesulitan dalam memahami materi dan tugas, ketersediaan dan kondisi jaringan internet. Agar kesulitan belajar mahasiswa dapat dijabarkan dengan rinci dan terarah maka dirasa perlu dilakukan penelitian tentang identifikasi kesulitan belajar mahasiswa khususnya pada mata kuliah statistika selama masa pandemi Covid-19 dengan menguraikan kesulitan-kesulitan yang mungkin dialami mahasiswa.

Adapun yang menjadi tujuan penelitian adalah untuk (1) mengetahui faktor-faktor penyebab kesulitan belajar mahasiswa pada mata kuliah Statistika selama masa pandemi Covid-19. (2) Mengetahui faktor dominan penyebab kesulitan belajar mahasiswa pada mata kuliah Statistika selama masa pandemi Covid-19.

\section{METODE}

Penelitian ini merupakan penelitian deskriptif kuantitatif karena bertujuan untuk mendeskripsikan suatu fenomena, peristiwa atau gejala yang terjadi secara faktual dan sistematis. Populasi dalam penelitian ini adalah mahasiswa Sekolah Tinggi Ilmu Ekonomi (STIE) Indragiri yang mengambil mata kuliah Statistika yang berjumlah 340 orang. Pengambilan sampel menggunakan teknik random sampling dimana setiap mahasiswa mendapat kesempatan yang sama untuk dijadikan sampel. Sampel yang diteliti diambil menggunakan rumus Slovin dengan error tolerance sebesar 5\% sehingga di dapat:

$n=\frac{N}{1+N e^{2}}=\frac{340}{1+340 \times 0,05^{2}}=184$ orang

Keterangan:

n : Jumlah sampel

$\mathrm{N} \quad$ : Jumlah populasi

e : Tingkat kesalahan (error tolerance)

(Husein, 2011)

Instrumen pengumpul data yang dikembangkan dalam penelitian ini berupa kombinasi angket tertutup dan terbuka mengenai kesulitan belajar mahasiswa pada mata kuliah statistika dengan 4 indikator, yaitu faktor dari diri sendiri (mahasiswa), faktor dari dosen, faktor lingkungan/ orang tua dan faktor sarana prasarana. Analisis data menggunakan teknik analisis statistik deskriptif yaitu penyajian data dalam bentuk tabel (menghitung tingkat capaian rata-rata), histogram atau poligon serta menghitung ukuran pemusatan data

\section{HASIL DAN PEMBAHASAN Karakteristik Responden}

Karakteristik responden meliputi jenis kelamin dan status pekerjaan. Dari 184 responden didapatkan informasi sebanyak 75 orang responden berjenis kelamin laki-laki dan 109 orang berjenis kelamin perempuan. Persentase berdasarkan jenis kelamin terlihat pada Gambar 2. di bawah ini.

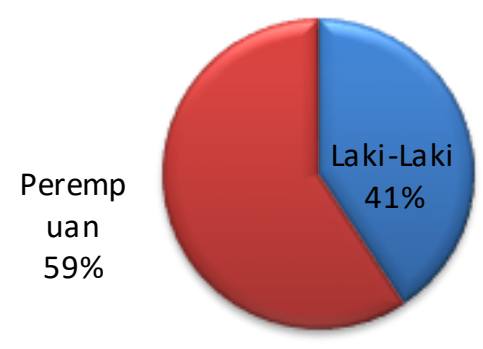

Gambar 2. Jenis Kelamin Responden

Adapun karakteristik berdasarkan status pekerjaan responden sebanyak 134 orang responden belum bekerja 
sedangkan 50 orang responden sudah bekerja. Persentase berdasarkan status pekerjaan terlihat pada Gambar 3. di bawah ini.

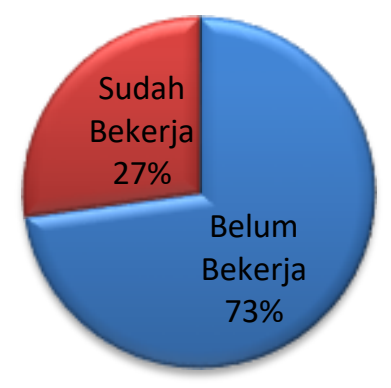

Gambar 3. Status Pekerjaan Responden

\section{Uji Validitas Instrumen}

Tabel 1.Hasil Uji Validitas Kuesioner

\begin{tabular}{|c|c|c|c|c|c|c|c|}
\hline Per & $\begin{array}{l}\text { Nilai } \\
\mathbf{r}_{\text {hitung }}\end{array}$ & $\begin{array}{l}\text { Nilai } \\
\mathbf{r}_{\text {tabel }}\end{array}$ & Ket & Per & $\begin{array}{l}\text { Nilai } \\
\mathbf{r}_{\text {hitung }}\end{array}$ & $\begin{array}{l}\text { Nilai } \\
\mathbf{r}_{\text {tabel }}\end{array}$ & Ket \\
\hline $\mathrm{P} 1$ & 0,420 & & Valid & P16 & 0,471 & & Valid \\
\hline $\mathrm{P} 2$ & 0,492 & & Valid & P17 & 0,576 & & Valid \\
\hline P3 & 0,399 & & Valid & P18 & 0,437 & & Valid \\
\hline P4 & 0,353 & & Valid & P19 & 0,515 & & Valid \\
\hline P5 & 0,526 & & Valid & $\mathrm{P} 20$ & 0,460 & & Valid \\
\hline P6 & 0,555 & & Valid & $\mathrm{P} 21$ & 0,732 & & Valid \\
\hline P7 & 0,711 & & Valid & $\mathrm{P} 22$ & 0,498 & 0173 & Valid \\
\hline P8 & 0,466 & 0,173 & Valid & $\mathrm{P} 23$ & 0,597 & 0,173 & Valid \\
\hline P9 & 0,487 & & Valid & P24 & 0,641 & & Valid \\
\hline P10 & 0,516 & & Valid & $\mathrm{P} 25$ & 0,659 & & Valid \\
\hline P11 & 0,583 & & Valid & P26 & 0,577 & & Valid \\
\hline P12 & 0,526 & & Valid & P27 & 0,418 & & Valid \\
\hline $\mathrm{P} 13$ & 0,563 & & Valid & P28 & 0,399 & & Valid \\
\hline P14 & 0,367 & & Valid & P29 & 0,594 & & Valid \\
\hline P15 & 0,587 & & Valid & & & & \\
\hline
\end{tabular}

Sumber: Data Olahan

Berdasarkan Tabel 1 di atas dapat dilihat bahwa semua pernyataan dengan nilai $r_{\text {hitung }}>$ nilai $r_{\text {tabel }}$, dapat disimpulkan bahwa semua pernyataan adalah valid.

\section{Uji Reliabilitas}

Tabel 2. Hasil Uji Reliabilitas

Reliability Statistics

Cronbach's Alpha N of Items

.90129

Sumber: Data Olahan

Berdasarkan Tabel 2 di atas, dapat dilihat nilai reliabilitas dengan menggunakan metode Cronbach's Alpha, bahwa semua nilai $\mathrm{r}_{\text {hitung }}(0,901)>\mathrm{r}_{\text {table }}(0,173)$, sehingga dapat disimpulkan bahwa semua pernyataan pada kuesioner dinyatakan sangat reliabel sebagai alat untuk mengumpulkan data dan dapat digunakan kedalam analisis lebih lanjut.

\section{Faktor-Faktor Kesulitan Belajar}

Sebelum dibahas mengenai faktor-faktor apa saja yang menjadi kesulitan belajar mahasiswa pada mata kuliah statistika di masa pandemi Covid-19, akan diuraikan terlebih dahulu bagaimana aktivitas belajar mahasiswa selama masa pandemi. Pembelajaran yang biasanya dilakukan secara tatap muka antara dosen dan mahasiswa, kini dengan adanya pandemi Covid-19 maka pembelajaran dilakukan dari rumah dan secara daring. Aktivitas belajar secara daring pada mata kuliah statistika ini dengan menggunakan Whatsaap Group, Zoom, Google Classroom dan Google Class Meet. Keadaan ini memaksa dosen dan mahasiswa untuk bisa mengadaptasi agar bisa mengikuti pembelajaran dengan baik. Namun pada kenyataannya keadaan ini justru memunculkan banyak kesulitan-kesulitan dalam mengikuti pembelajaran pada mata kuliah statistika. Berikut akan dijabarkan faktor-faktor yang dihadapi mahasiswa pada mata kuliah statistika selama masa pandemi Covid-19.

\section{Faktor Diri Sendiri}

Kesulitan belajar mahasiswa pada mata kuliah statistika selama pandemi Covid-19 yang berasal dari faktor diri sendiri dapat dilihat pada Tabel 3, adapun mahasiswa yang berpartisipasi sebagai responden sebanyak 184 orang. Data dianalisis dan dihitung untuk mengetahui skor rata-rata dan persentase Tingkat Capaian Responden (TCR). Hasil indeks persentase menunjukkan jenis dan faktor yang berasal dari diri sendiri yang berkaitan dengan kesulitan belajar statistika.

Tabel 3. Faktor Diri Sendiri

\begin{tabular}{l|l|c|c|c|c|c}
\hline No & $\begin{array}{l}\text { Indikato } \\
\mathbf{r}\end{array}$ & Sampel & $\begin{array}{c}\text { Mi } \\
\mathbf{n}\end{array}$ & $\begin{array}{c}\text { Ma } \\
\mathbf{x}\end{array}$ & $\begin{array}{c}\text { Me- } \\
\text { an }\end{array}$ & TCR \\
\hline 1 & DS 1 & 184 & 1 & 4 & 2,40 & $60,00 \%$ \\
2 & DS 2 & 184 & 1 & 4 & 2,60 & $65,00 \%$ \\
3 & DS 3 & 184 & 1 & 4 & 2,17 & $54,25 \%$ \\
4 & DS 4 & 184 & 1 & 4 & 2,28 & $57,00 \%$ \\
5 & DS 5 & 184 & 1 & 4 & 2,05 & $51,25 \%$ \\
6 & DS 6 & 184 & 1 & 4 & 1,88 & $47,00 \%$ \\
7 & DS 7 & 184 & 1 & 3 & 1,80 & $45,00 \%$ \\
8 & DS 8 & 184 & 1 & 3 & 2,47 & $61,75 \%$ \\
9 & DS 9 & 184 & 1 & 4 & 2,35 & $58,75 \%$ \\
10 & DS 10 & 184 & 1 & 4 & 2,08 & $52,00 \%$ \\
11 & DS 11 & 184 & 1 & 4 & 2,77 & $69,25 \%$ \\
12 & DS 12 & 184 & 1 & 4 & 2,33 & $58,25 \%$ \\
13 & DS 13 & 184 & 1 & 3 & 1,89 & $47,25 \%$ \\
\hline \multicolumn{6}{l}{ Rata-Rata } \\
Faktor Diri Sendiri & & & & \\
Sumbery Da Olanan
\end{tabular}

Sumber: Data Olahan

DS 1 merupakan pernyataan mengenai persepsi mahasiswa yang menganggap bahwa mata kuliah Statistika merupakan mata kuliah yang sulit. Didapatkan nilai mean dan TCR masing-masing sebesar 2,40 dan $60,00 \%$. Artinya indikator DS 1 masuk dalam kategori cukup. Dapat disimpulkan bahwa indikator DS 1 
menjadi faktor yang cukup besar didalam kesulitan belajar mahasiswa pada mata kuliah Statistika selama masa pandemi Covid-19.

DS 2 merupakan pernyataan mengenai kesulitan mahasiswa untuk memahami istilah/notasi rumus dalam mata kuliah Statistika. Didapatkan nilai mean dan TCR masing-masing sebesar 2,60 dan 65,00\%. Artinya indikator DS 2 masuk dalam kategori kuat. Dapat disimpulkan bahwa indikator DS 2 menjadi faktor yang kuat didalam kesulitan belajar mahasiswa pada mata kuliah Statistika selama masa pandemi Covid-19.

DS 3 merupakan pernyataan mengenai rendahnya antusiasme mahasiswa untuk bertanya kepada dosen atau teman apabila mengalami kesulitan dalam mata kuliah Statistika. Didapatkan nilai mean dan TCR masingmasing sebesar 2,17 dan 54,25\%. Artinya indikator DS 3 masuk dalam kategori cukup. Dapat disimpulkan bahwa indikator DS 3 menjadi faktor yang cukup besar didalam kesulitan belajar mahasiswa pada mata kuliah Statistika selama masa pandemi Covid-19.

DS 4 merupakan pernyataan mengenai rendahnya keaktifan mahasiswa saat perkuliahan berlangsung. Didapatkan nilai mean dan TCR masing-masing sebesar 2,28 dan $57,00 \%$. Artinya indikator DS 4 masuk dalam kategori cukup. Dapat disimpulkan bahwa indikator DS 4 menjadi faktor yang cukup besar didalam kesulitan belajar mahasiswa pada mata kuliah Statistika selama masa pandemi Covid-19.

DS 5 merupakan pernyataan mengenai perilaku mahasiswa yang menyontek jawaban teman pada saat mengerjakan tugas atau ujian mata kuliah Statistika. Didapatkan nilai mean dan TCR masing-masing sebesar 2,05 dan $51,25 \%$. Artinya indikator DS 5 masuk dalam kategori cukup. Dapat disimpulkan bahwa indikator DS 5 menjadi faktor yang cukup besar didalam kesulitan belajar mahasiswa pada mata kuliah Statistika selama masa pandemi Covid-19.

DS 6 merupakan pernyataan mengenai rendahnya semangat mahasiswa dalam mengikuti mata kuliah Statistika. Didapatkan nilai mean dan TCR masingmasing sebesar 1,88 dan 47,00\%. Artinya indikator DS 6 masuk dalam kategori cukup. Dapat disimpulkan bahwa indikator DS 6 menjadi faktor yang cukup besar didalam kesulitan belajar mahasiswa pada mata kuliah Statistika selama masa pandemi Covid-19.

DS 7 merupakan pernyataan mengenai kurangnya perhatian mahasiswa saat dosen menjelaskan materi Statistika. Didapatkan nilai mean dan TCR masingmasing sebesar 1,80 dan $45,00 \%$. Artinya indikator DS 7 masuk dalam kategori cukup. Dapat disimpulkan bahwa indikator DS 7 menjadi faktor yang cukup besar didalam kesulitan belajar mahasiswa pada mata kuliah Statistika selama masa pandemi Covid-19.

DS 8 merupakan pernyataan mengenai kebiasaan mahasiswa yang tidak pernah mengulang materi Statistika diluar jam perkuliahan. Didapatkan nilai mean dan TCR masing-masing sebesar 2,47 dan 61,75\%.
Artinya indikator DS 8 masuk dalam kategori kuat. Dapat disimpulkan bahwa indikator DS 8 menjadi faktor yang kuat didalam kesulitan belajar mahasiswa pada mata kuliah Statistika selama masa pandemi Covid-19.

DS 9 merupakan pernyataan mengenai rendahnya inisiatif mahasiswa dalam mencari sumber lain untuk mendukung pengetahuan tentang materi Statistika. Didapatkan nilai mean dan TCR masing-masing sebesar 2,35 dan 58,75\%. Artinya indikator DS 9 masuk dalam kategori cukup. Dapat disimpulkan bahwa indikator DS 1 menjadi faktor yang cukup besar didalam kesulitan belajar mahasiswa pada mata kuliah Statistika selama masa pandemi Covid-19.

DS 10 merupakan pernyataan bahwa mahasiswa akan belajar Statistika ketika akan menghadapi ujian. Didapatkan nilai mean dan TCR masing-masing sebesar 2,08 dan 52,00\%. Artinya indikator DS 10 masuk dalam kategori cukup. Dapat disimpulkan bahwa indikator DS 10 menjadi faktor yang cukup besar didalam kesulitan belajar mahasiswa pada mata kuliah Statistika selama masa pandemi Covid-19.

DS 11 merupakan pernyataan mengenai kesulitan untuk mengingat kembali materi pelajaran statistika yang memerlukan keterampilan menghitung. Didapatkan nilai mean dan TCR masing-masing sebesar 2,77 dan 69,25\%. Artinya indikator DS 11 masuk dalam kategori kuat. Dapat disimpulkan bahwa indikator DS 11 menjadi faktor yang kuat didalam kesulitan belajar mahasiswa pada mata kuliah Statistika selama masa pandemi Covid19.

DS 12 merupakan pernyataan mengenai adanya kesulitan dalam mengikuti teknologi yang digunakan oleh dosen selama pembelajaran Statistika daring. Didapatkan nilai mean dan TCR masing-masing sebesar 2,33 dan 58,25\%. Artinya indikator DS 12 masuk dalam kategori cukup. Dapat disimpulkan bahwa indikator DS 12 menjadi faktor yang cukup besar didalam kesulitan belajar mahasiswa pada mata kuliah Statistika selama masa pandemi Covid-19.

DS 13 merupakan pernyataan mengenai adanya gangguan saat proses pembelajaran Statistika karena riwayat kesehatan yang buruk (gangguan penglihatan dan pendengaran yang kurang baik). Didapatkan nilai mean dan TCR masing-masing sebesar 1,89 dan 47,25\%. Artinya indikator DS 13 masuk dalam kategori cukup. Dapat disimpulkan bahwa indikator DS 13 menjadi faktor yang cukup besar didalam kesulitan belajar mahasiswa pada mata kuliah Statistika selama masa pandemi Covid-19.

Nilai TCR yang terbesar adalah indikator DS 11 sebesar $69,25 \%$ yaitu mengenai kesulitan mahasiswa untuk mengingat kembali materi pelajaran statistika yang memerlukan keterampilan menghitung. Selanjutnya diikuti indikator DS 2 dan DS 8 dengan nilai TCR masing-masing 65\% dan 61,75\%, mengenai kesulitan untuk memahami istilah/ notasi rumus dalam mata kuliah statistika dan mahasiswa tidak pernah 
mengulang materi statistika diluar jam perkuliahan. Hasil penelitian ini sejalan dengan penelitian yang dilakukan oleh Oktawirawan (2020) yang menyatakan pemicu kecemasan siswa selama pembelajaran daring adalah kesulitan memahami materi dan kesulitan mengerjakan tugas. Mediyani (2020) juga menyatakan bahwa rata-rata siswa sulit memahami maksud dari soal dan sulit menentukan bagaimana cara menyelesaikannya. Kesulitan yang berasal dari diri sendiri tentang minat belajar, motivasi belajar dan kemampuan belajar juga telah dibuktikan pada penelitian Nurdianto (2020). Oleh karena itu mahasiswa perlu adaptasi belajar selama masa pandemi agar tidak terjadi stress belajar (Harahap, 2020). Maka dapat diambil kesimpulan bahwa sebagian besar mahasiswa mempunyai persepsi bahwa mata kuliah statistika adalah mata kuliah yang sulit. Hal ini sejalan dengan penelitian yang dilakukan oleh Ririen (2019) bahwa persepsi mahasiswa berpengaruh terhadap prestasi belajarnya.

\section{Faktor Dosen}

Hasil indeks persentase menunjukkan faktor yang berasal dari dosen atau tenaga pengajar yang berkaitan dengan kesulitan belajar statistika terdiri dari 7 indikator. Berikut adalah 7 indikator dari faktor dosen yang akan diuraikan pada Tabel 4.

Tabel 4. Faktor Dosen

\begin{tabular}{lllllll}
\hline $\begin{array}{l}\text { N } \\
\mathbf{0}\end{array}$ & $\begin{array}{l}\text { Indikato } \\
\text { r }\end{array}$ & Sampel & $\begin{array}{l}\text { Mi } \\
\mathbf{n}\end{array}$ & $\begin{array}{l}\text { Ma } \\
\mathbf{x}\end{array}$ & Mean & TCR \\
\hline 1 & D 1 & 184 & 1 & 4 & 2,22 & $55,50 \%$ \\
2 & D 2 & 184 & 1 & 4 & 1,98 & $49,50 \%$ \\
3 & D 3 & 184 & 1 & 4 & 1,97 & $49,25 \%$ \\
4 & D 4 & 184 & 1 & 4 & 2,01 & $50,25 \%$ \\
5 & D 5 & 184 & 1 & 4 & 2,10 & $52,50 \%$ \\
6 & D 6 & 184 & 1 & 4 & 1,92 & $48,00 \%$ \\
7 & D 7 & 184 & 1 & 4 & 2,20 & $55,00 \%$ \\
\hline \multicolumn{2}{l}{ Rata-Rata } & & & & & \\
Faktor Dosen & & & & 2,06 & $51,43 \%$ \\
\hline
\end{tabular}

Sumber: Data Olahan

D1 merupakan pernyataan bahwa dosen tidak menggunakan media pembelajaran yang bervariasi selama masa pandemi. Didapatkan nilai mean dan TCR masing-masing sebesar 2,22 dan 55,50\%. Artinya indikator D1 masuk dalam kategori cukup. Dapat disimpulkan bahwa indikator D1 menjadi faktor yang cukup besar didalam kesulitan belajar mahasiswa pada mata kuliah Statistika selama masa pandemi Covid-19.

D2 merupakan pernyataan mengenai dosen statistik tidak membimbing mahasiswa saat pembelajaran selama masa pandemi. Didapatkan nilai mean dan TCR masing-masing sebesar 1,98 dan 49,50\%. Artinya indikator D2 masuk dalam kategori cukup. Dapat disimpulkan bahwa indikator D2 menjadi faktor yang cukup besar didalam kesulitan belajar mahasiswa pada mata kuliah Statistika selama masa pandemi Covid19.

D3 merupakan pernyataan mengenai dosen statistik hanya memberikan tugas-tugas tanpa penjelasan selama masa pandemi. Didapatkan nilai mean dan TCR masing-masing sebesar 1,97 dan $49,25 \%$. Artinya indikator D3 masuk dalam kategori cukup. Dapat disimpulkan bahwa indikator D3 menjadi faktor yang cukup besar didalam kesulitan belajar mahasiswa pada mata kuliah Statistika selama masa pandemi Covid-19.

D4 merupakan pernyataan mengenai dosen statistik tidak bersedia membimbing mahasiswa secara pribadi selama masa pandemi. Didapatkan nilai mean dan TCR masing-masing sebesar 2,01 dan 50,25\%. Artinya indikator D4 masuk dalam kategori cukup. Dapat disimpulkan bahwa indikator D4 menjadi faktor yang cukup besar didalam kesulitan belajar mahasiswa pada mata kuliah Statistika selama masa pandemi Covid19.

D5 merupakan pernyataan mengenai dosen statistik tidak mengembalikan tugas-tugas selama masa pandemi. Didapatkan nilai mean dan TCR masingmasing sebesar 2,10 dan 52,50\%. Artinya indikator D5 masuk dalam kategori cukup. Dapat disimpulkan bahwa indikator D5 menjadi faktor yang cukup besar didalam kesulitan belajar mahasiswa pada mata kuliah Statistika selama masa pandemi Covid-19.

D6 merupakan pernyataan bahwa dosen statistik kurang baik dalam menerangkan setiap materi perkuliahan selama masa pandemi. Didapatkan nilai mean dan TCR masing-masing sebesar 1,92 dan 48,00\%. Artinya indikator D6 masuk dalam kategori cukup. Dapat disimpulkan bahwa indikator D6 menjadi faktor yang cukup besar didalam kesulitan belajar mahasiswa pada mata kuliah Statistika selama masa pandemi Covid19.

D7 merupakan pernyataan mengenai metode pembelajaran yang digunakan oleh dosen statistika selama masa pandemi kurang menarik. Didapatkan nilai mean dan TCR masing-masing sebesar 2,20 dan 55,00\%. Artinya indikator D7 masuk dalam kategori cukup. Dapat disimpulkan bahwa indikator D7 menjadi faktor yang cukup besar didalam kesulitan belajar mahasiswa pada mata kuliah Statistika selama masa pandemi Covid19.

Berdasarkan rekapitulasi jawaban responden dari faktor dosen dapat dilihat indikator dengan nilai TCR tertinggi adalah D1 yaitu sebesar $55,5 \%$ yang menyatakan bahwa dosen statistika belum menggunakan media pembelajaran yang bervariasi selama masa pandemi Covid-19. Diikuti indikator D7 tentang metode pembelajaran yang digunakan oleh dosen statistika selama masa pandemi kurang menarik dengan nilai TCR sebesar 55\%. Hal ini sejalan dengan penelitian yang dilakukan oleh Annur (2020) yang menyatakan kesulitan pembelajaran daring dapat disebabkan ketidaksiapan tenaga pengajar. (Sucipto, 
2016) juga menyatakan bahwa faktor dosen merupakan salah satu penyebab kesulitan belajar mahasiswa dalam hal dari gaya mengajar dan metode pembelajaran.

\section{Faktor Lingkungan/ Orang Tua}

Hasil indeks persentase menunjukkan faktor yang berasal dari lingkungan/ orang tua yang berkaitan dengan kesulitan belajar statistika terdiri dari 5 indikator. Berikut adalah 5 indikator dari faktor lingkungan/ orang tua yang akan diuraikan pada Tabel 5 .

Tabel 5. Faktor Lingkungan/ Orang Tua

\begin{tabular}{lllllll}
\hline No & Indikator & Sampel & Min & Max & Mean & TCR \\
\hline 1 & LOT 1 & 184 & 1 & 4 & 1,86 & 46,50 \\
2 & LOT 2 & 184 & 1 & 4 & 1,81 & 45,25 \\
3 & LOT 3 & 184 & 1 & 4 & 1,95 & 48,75 \\
4 & LOT 4 & 184 & 1 & 4 & 2,45 & 61,25 \\
5 & LOT 5 & 184 & 1 & 4 & 2,42 & 60,50 \\
\hline Rata-Rata & & & & & \\
Lingkungan/ & & & & 2,10 & $52,45 \%$ \\
Orang Tua & & & & & \\
\hline
\end{tabular}

Sumber: Data Olahan

LOT 1 merupakan pernyataan mengenai kurangnya perhatian dari orang tua yang membuat mahasiswa tidak semangat untuk belajar. Didapatkan nilai mean dan TCR masing-masing sebesar 1,86 dan 46,50\%. Artinya indikator LOT 1 masuk dalam kategori cukup. Dapat disimpulkan bahwa indikator LOT 1 menjadi faktor yang cukup besar didalam kesulitan belajar mahasiswa pada mata kuliah Statistika selama masa pandemi Covid-19.

LOT 2 merupakan pernyataan mengenai orang tua mahasiswa yang tidak memfasilitasi dalam pembelajaran daring. Didapatkan nilai mean dan TCR masing-masing sebesar 1,81 dan 45,25\%. Artinya indikator LOT 2 masuk dalam kategori cukup. Dapat disimpulkan bahwa indikator LOT 2 menjadi faktor yang cukup besar didalam kesulitan belajar mahasiswa pada mata kuliah Statistika selama masa pandemi Covid-19.

LOT 3 merupakan pernyataan mengenai orang tua mahasiswa yang tidak pernah/ jarang memperhatikan nilai akademik. Didapatkan nilai mean dan TCR masingmasing sebesar 1,95 dan $48,75 \%$. Artinya indikator LOT 3 masuk dalam kategori cukup. Dapat disimpulkan bahwa indikator LOT 3 menjadi faktor yang cukup besar didalam kesulitan belajar mahasiswa pada mata kuliah Statistika selama masa pandemi Covid-19.

LOT 4 merupakan pernyataan mengenai kondisi sosial ekonomi keluarga kurang mendukung proses pembelajaran daring. Didapatkan nilai mean dan TCR masing-masing sebesar 2,45 dan 61,25\%. Artinya indikator LOT 4 masuk dalam kategori kuat. Dapat disimpulkan bahwa indikator LOT 4 menjadi faktor yang kuat didalam kesulitan belajar mahasiswa pada mata kuliah Statistika selama masa pandemi Covid-19.
LOT 5 merupakan pernyataan mengenai suasana lingkungan di sekitar rumah kurang mendukung proses pembelajaran daring dikarenakan dekat dengan keramaian. Didapatkan nilai mean dan TCR masingmasing sebesar 2,42 dan 60,50\%. Artinya indikator LOT 5 masuk dalam kategori cukup. Dapat disimpulkan bahwa indikator LOT 5 menjadi faktor yang cukup besar didalam kesulitan belajar mahasiswa pada mata kuliah Statistika selama masa pandemi Covid-19.

Berdasarkan rekapitulasi jawaban responden untuk kesulitan belajar mahasiswa dari faktor lingkungan/ orang tua dengan nilai TCR tertingginya adalah indikator LOT 4 sebesar $61,25 \%$ yang menyatakan bahwa kondisi sosial ekonomi keluarga kurang mendukung proses pembelajaran daring. Disusul indikator LOT 5 dengan nilai TCR 60,50\% mengenai suasana lingkungan di sekitar rumah kurang mendukung proses pembelajaran daring dikarenakan dekat dengan keramaian.

Dengan dilakukannya pembelajaran secara daring maka tentunya akan menggunakan media pembelajaran yang menggunakan kuota. Hal ini tentunya membutuhkan biaya untuk membeli kuota internet, sementara itu banyak dari mahasiswa yang memiliki keterbatasan secara finansial. Sejalan dengan penelitian yang dilakukan Sadikin et al. (2020) bahwa mahalnya biaya kuota adalah tantangan tersendiri dalam pembelajaran daring. Mengenai suasana lingkungan di sekitar rumah yang kurang mendukung proses pembelajaran daring hal ini dikarenakan beberapa mahasiswa tinggal di wilayah seperti lingkungan perumahan yang padat dan ramai maupun lingkungan yang berdekatan dengan fasilitas/ sarana umum yang menimbulkan keramaian. Sehingga mereka tidak bisa belajar dengan nyaman di dalam rumah.

\section{Faktor Sarana Prasarana}

Hasil indeks persentase menunjukkan faktor yang berasal dari sarana prasarana yang berkaitan dengan kesulitan belajar statistika terdiri dari 4 indikator. Berikut adalah 4 indikator dari faktor sarana prasarana yang akan diuraikan pada Tabel 6 .

Tabel 6. Faktor Sarana Prasarana

\begin{tabular}{lllllll}
\hline No & Indikator & Sampel & Min & Max & Mean & TCR \\
\hline 1 & SP 1 & 184 & 1 & 4 & 1,99 & $49,75 \%$ \\
2 & SP 2 & 184 & 1 & 4 & 2,90 & $72,50 \%$ \\
3 & SP 3 & 184 & 1 & 4 & 2,85 & $71,25 \%$ \\
4 & SP 4 & 184 & 1 & 4 & 2,56 & $64,00 \%$ \\
\hline $\begin{array}{l}\text { Rata-Rata } \\
\text { Faktor }\end{array}$ \\
$\begin{array}{l}\text { Prasarana } \\
\text { Prana }\end{array}$
\end{tabular}

Sumber: Data Olahan

SP 1 merupakan pernyataan mengenai bahwa mahasiswa tidak memiliki fasilitas yang mendukung proses pembelajaran daring (laptop,HP). Didapatkan nilai mean dan TCR masing-masing sebesar 1,99 dan $49,75 \%$. Artinya indikator SP 1 masuk dalam kategori 
cukup. Dapat disimpulkan bahwa indikator SP 1 menjadi faktor yang cukup besar didalam kesulitan belajar mahasiswa pada mata kuliah Statistika selama masa pandemi Covid-19.

SP 2 merupakan pernyataan mengenai signal di daerah mereka yang tidak mendukung proses pembelajaran secara daring. Didapatkan nilai mean dan TCR masing-masing sebesar 2,90 dan 72,50\%. Artinya indikator SP 2 masuk dalam kategori kuat. Dapat disimpulkan bahwa indikator SP 2 menjadi faktor yang kuat didalam kesulitan belajar mahasiswa pada mata kuliah Statististik selama masa pandemi Covid-19.

SP 3 merupakan pernyataan mengenai seringnya terjadi gangguan listrik di daerah mereka. Didapatkan nilai mean dan TCR masing-masing sebesar 2,85 dan $71,25 \%$. Artinya indikator SP 3 masuk dalam kategori kuat. Dapat disimpulkan bahwa indikator SP 3 menjadi faktor yang kuat didalam kesulitan belajar mahasiswa pada mata kuliah Statistika selama masa pandemi Covid19.

SP 4 merupakan pernyataan mengenai suasana di rumah kurang mendukung proses pembelajaran secara daring. Didapatkan nilai mean dan TCR masing-masing sebesar 2,56 dan 64,00\%. Artinya indikator SP 4 masuk dalam kategori kuat. Dapat disimpulkan bahwa indikator SP 4 menjadi faktor yang kuat didalam kesulitan belajar mahasiswa pada mata kuliah Statistika selama masa pandemi Covid-19.

Berdasarkan rekapitulasi jawaban responden dalam kesulitan belajar mahasiswa dari faktor sarana prasarana didapatkan nilai TCR tertinggi adalah indikator SP 2 sebesar 72,50\% yang menyatakan bahwa signal di daerah saya tidak mendukung proses pembelajaran secara daring. Diikuti indikator SP 3 dengan nilai TCR $71,25 \%$ mengenai seringnya terjadi gangguan listrik di daerah mereka dan disusul indikator SP 4 mengenai suasana di rumah kurang mendukung proses pembelajaran secara daring dengan nilai TCR $64,00 \%$.

Hal ini sejalan dengan penelitian yang dilakukan oleh Oktawirawan (2020) menyatakan pemicu kecemasan siswa selama pembelajaran daring selain kesulitan memahami materi dan kesulitan mengerjakan tugas adalah kesulitan jaringan internet. Kesulitan jaringan internet ini biasanya diperparah dengan kondisi listrik yang sering mengalami gangguan. Jika terjadi pemadaman listrik di daerah maka biasanya akan berpengaruh pada gangguan jaringan internet. Hal ini yang sering terjadi untuk mahasiswa yang tinggal di daerah pelosok dikarenakan minimnya akses internet. Hal ini yang membuat mahasiswa kehilangan konsentrasi ketika menghadapi sinyal atau jaringan internet yang tidak optimal. Sejalan dengan penelitian Sadikin et al. (2020) yang menyatakan bahwa kesulitan belajar selama pandemi salah satunya adalah kurang kuatnya signal di daerah pelosok.
Banyak mahasiswa yang menyatakan jika lingkungan rumah kurang kondusif untuk belajar, terlalu banyak gangguan seperti adik, orang tua bahkan rasa tidak nyaman dan tidak tenang karena melakukan pembelajaran di rumah. Hal ini sejalan dengan penelitian yang dilakukan oleh Maryati (2017) yang menyatakan bahwa lingkungan keluarga kurang mendukung dalam menciptakan suasana kondusif untuk melakukan pembelajaran dari rumah.

\section{Faktor Dominan Kesulitan Belajar Mahasiswa Mata Kuliah Statistika Selama Masa Pandemi Covid-19}

Hasil rekapitulasi kuesioner yang telah diolah yang terdiri dari 4 faktor yaitu faktor diri sendiri, faktor dosen, faktor lingkungan/ orang tua serta faktor sarana prasarana disajikan dalam Tabel 7.

Tabel 7. Rekapitulasi Faktor-Faktor Kesulitan Belajar Mahasiswa

\begin{tabular}{l|l|l|l}
\hline No & Faktor Kesulitan Belajar & Mean & TCR \\
\hline 1 & Faktor Diri Sendiri & 2,24 & $55,90 \%$ \\
2 & Faktor Dosen & 2,06 & $51,43 \%$ \\
3 & Faktor Lingkungan/ Orang Tua & 2,10 & $52,45 \%$ \\
4 & Faktor Sarana Prasarana & 2,58 & $64,38 \%$ \\
\hline
\end{tabular}

Sumber: Data Olahan

Berdasarkan Tabel 7. maka dapat disimpulkan bahwa faktor yang paling kuat pengaruhnya terhadap kesulitan belajar mahasiswa pada mata kuliah statistika selama masa pandemi covid-19 adalah faktor sarana prasarana dengan nilai TCR $64,38 \%$. Selama proses pembelajaran secara daring, sebagian besar mahasiswa terkendala dengan jaringan internet khususnya mahasiswa yang tinggal di daerah pelosok serta sering terjadinya gangguan listrik.

Faktor urutan kedua yang menjadi kesulitan belajar mahasiswa adalah faktor diri sendiri dengan nilai TCR 55,90\%. Sebagian besar mahasiswa belum berupaya untuk beradaptasi dengan proses pembelajaran selama masa pandemi, misalnya belajar mandiri untuk berupaya memahami materi yang diberikan, manajemen diri serta keaktifan mencari sumber belajar yang mendukung pembelajaran.

Faktor urutan ketiga adalah faktor lingkungan/ orang tua dengan nilai TCR 52,45\%. Kesulitan belajar yang dihadapi mahasiswa selama pembelajaran daring adalah kebutuhan biaya untuk membeli kuota internet yang terbilang mahal, ironisnya sebagian besar mahasiswa memiliki kondisi sosial ekonomi keluarga yang kurang mendukung selama pembelajaran. Selain itu mahasiswa beranggapan faktor suasana lingkungan di sekitar rumah yang dekat dengan keramaian juga merupakan kesulitan belajar selama masa pandemi karena dianggap kurang kondusif untuk melakukan proses pembelajaran dari rumah.

Faktor terakhir yang merupakan faktor dengan nilai TCR terendah adalah faktor dosen dengan nilai 
TCR 51,43\%. Dosen berperan sebagai orang yang mentransfer ilmu pengetahuan dirasa perlu untuk selalu upgrade dengan perkembangan zaman teknologi mulai dari metode mengajar yang digunakan, media pembelajaran sebagai alat bantu pembelajaran serta memahami karakteristik peserta didik. Dalam hal ini dosen statistika sudah melakukan berbagai media pembelajaran baik menggunakan Zoom, Google Classroom, Google Meet, Youtube, dan Whatsapp Group. Walaupun dalam kenyataannya masih terdapat banyak kesulitan yang dialami seperti kendala jaringan mahasiswa yang tidak bisa mengakses media pembelajaran tersebut.

\section{SIMPULAN}

Berdasarkan pada permasalahan penelitian dan analisis yang dihasilkan, maka kesimpulan yang dapat diambil pada penelitian ini adalah sebagai berikut:

1. Faktor-faktor yang menjadi kesulitan belajar mahasiswa pada mata kuliah statistika selama masa pandemi Covid-19 adalah faktor diri sendiri terdapat, faktor dosen, faktor lingkungan/ orang tua terdapat dan faktor sarana dan prasarana.

2. Faktor yang paling dominan berpengaruh terhadap kesulitan belajar mahasiswa pada mata kuliah statistika selama masa pandemi Covid-19 adalah faktor sarana prasarana.

\section{DAFTAR PUSTAKA}

Annur, M. F. (2020). Analisis Kesulitan Mahasiswa Pendidikan Matematika. Jurnal Kajian, Penelitian Dan Pengembangan Kependidikan, 11(2), 195201.

Harahap, A. C. P. (2020). Covid 19: Self Regulated Learning Mahasiswa. Jurnal Pendidikan Dan Konseling, 10(1), 36-42.

Husein, Umar. 2011. Metode Penelitian Untuk Skripsi dan Tesis Bisnis Edisi 11. Jakarta: PT Raja Grafindo.

Maryati, I. (2017). Analisis kesulitan dalam materi statistika ditinjau dari kemampuan penalaran dan komunikasi statistis. Jurnal PRISMA Universitas Suryakencana, VI(2), 173-179.

Nurdianto, W. B. (2020). Analisis Kesulitan Belajar Statistika Mahasiswa Pendidikan Tata Boga. Medin Pendidikan Gizi Dan Kuliner, 9(1), 61-64.

Oktawirawan, dwi hardani. (2020). Faktor Pemicu Kecemasan Siswa dalam Melakukan Pembelajaran Daring di Masa Pandemi Covid-19. Jurnal Ilmiah Universitas Batanghari Jambi, 20(2), 541544.https://doi.org/10.33087/jiubj.v20i2.932

Ririen, D. (2019). Pengaruh Pengetahuan Awal Dan Persepsi Mahasiswa Terhadap Prestasi Belajar Statistika Ii Di Stie Indragiri Rengat. Jurnal Manajemen Dan Bisnis, VIII(01), 49-60.

Sadikin, A., Hamidah, A. (2020). Pembelajaran Daring di Tengah Wabah Covid-19 ( Online Learning in the Middle of the Covid-19 Pandemic). Jurnal Ilmiah Pendidikan Biologi, 6(1), 214-224.

Sucipto, L. (2016). Analisis kesulitan mahasiswa dalam memahami konsep bilangan real. Jurnal Tadris Matematika, 9(2), 197-211.

Zamista, A. A., Rahmi, H., Sellyana, A., \& Desriyati, W. (2020). Persepsi Mahasiswa Terhadap Pembelajaran Dalam Jaringan Untuk Mata Kuliah Kalkulus Student. Jurnal Theorems, 5(1), 41-48. 